\title{
Türkiye Cumhuriyeti'ne Yönelen Kitlesel Göç Hareketleri ve Kabul Mekanizmasındaki Yaklaşımlara İlişkin Bir İnceleme: 1989 Bulgaristan, 1991 Irak ve 2011 Suriye Göçleri
}

\author{
A Review of The Mass Migration Movements Towards The \\ Republic of Turkey and The Approaches in The Acceptance \\ Mechanism: 1989 Bulgaria, 1991 Iraq and 2011 Syria Migrations
}

\author{
Ahmet CEYLAN $^{1}$ (D) İsa USLU ${ }^{2}$ (1)
}

*Bu metin, Yakın Dönem Türkiye Tarihi II. Öğrenci Sempozyumu'nda sunulan bildirinin genișletilerek makale şekline getirilmiş halidir.

'Doktora Öğrencisi, Ege Üniversitesi Sosyal Bilimler Enstitüsü Coğrafya Bölümü Beșeri ve İktisadi Coğrafya Ana Bilim Dalı, İzmir, Türkiye

${ }^{2}$ Yüksek Lisans Öğrencisi, Dokuz Eylül

Üniversitesi, Sosyal Bilimler Enstitüsü, Kamu

Yönetimi Bölümü, İzmir, Türkiye

ORCID: A.C. 0000-0003-3032-2599;

i.U. 0000-0002-7795-7260

Sorumlu yazar/Corresponding author: İsa Uslu, İzmir, Türkiye

E-posta/E-mail: isa.uslu20@gmail.com

Başvuru/Submitted: 05.07.2019 Revizyon Talebi/Revision Requested: 06.11.2019

Son Revizyon/Last Revision Received: 09.11.2019

Kabul/Accepted: 16.12 .2019

Atıf/Citation: Ceylan, A. and Uslu, I. (2019) Türkiye Cumhuriyeti'ne yönelen kitlesel göç hareketleri ve kabul mekanizmasındaki yaklaşımlara ilişkin bir inceleme: 1989 Bulgaristan, 1991 Irak ve 2011 Suriye göçleri. Yakın Dönem Türkiye Araștırmaları-Recent Period Turkish Studies, 36: 199-221.

https://doi.org/10.26650/YTA2019-619967
ÖZ

Türkiye Cumhuriyeti, kuruluş sürecinden itibaren Anadolu coğrafyasının tarihsel devamlılığına uygun biçimde yoğun göç hareketleri ile karşı karşıya kalmıştır. Bahsi geçen göç hareketlerinin bir bölümü, sınır komşusu ülkelerdeki siyasal gelişmeleri takiben kitlesel hareketler çerçevesinde gerçekleşmiştir. Kitlesel sınır ötesi nüfus hareketleri içerisinde yakın tarihli üç göç, yoğunlukları ve karşılanış biçimleriyle özel bir öneme haiz olmuştur. 1989 Bulgaristan göçü, 1991 Irak göçü ve 2011 sonrası Suriye göçü bu bağlamda karşılaştırılabilir benzerlik ve farklılıklar taşımışlardır. Çalışma, ilgili göç hareketlerinin gelişim süreçleri ve Türkiye kamuoyunda bu göç hareketlerine karşı vücut bulan kabul politikalarındaki benzerlik ve farklılıkları, kuramsal yaklaşımlar ve Türk göç hukukunun tarihsel derinliği pencerelerinden hareketle ele almıştır.

Anahtar Kelimeler: Kitlesel Göç Hareketleri, 1989 Bulgaristan Göçü, 1991 Irak Göçü, 2011 Suriye Göçü

\section{ABSTRACT}

The Republic of Turkey has faced intense migration movements in accordance with the historical continuity of the Anatolian geography since its foundation process. Some of the mentioned migration movements took place within the framework of the mass movements following political developments in neighboring countries. The mass cross-border population movements have been of particular importance in the three recent migrations, with their intensities and the way they are met. The 1989 Bulgarian migration, the 1991 Iraqi migration and the Syrian migration after 2011 have been comparable, having similarities 
and differences in this context. The study focused on the development processes of related migration movements and the similarities and differences in the accepted policies of the Turkish public against these migration movements, theoretical approaches and the historical depth of the Turkish migration law.

Keywords: Mass Migration Movements, 1989 Bulgarian Migration, 1991 Iraqi Migration, 2011 Syrian Migration

\section{Giriș}

Göçmenliğin siyasal sebeplerden dolayı doğan kısmı, göç literatüründe ekseri olarak mültecilik ve sığınmacılık ekseninde ele alınmaktadır. Uluslararası göç hareketlerinde mültecilik hukuku Birinci Dünya Savaşı sonrası ilk kez kapsamlı olarak ele alınmaya başlamıştır. İkinci Dünya Savaşı sonrası Cenevre Sözleşmesi ile evrensel bir bağlam alan yapı; Türkiye Cumhuriyeti'nin tarihsel arka planında, kuruluşunda ve izleyen yıllarında önem arz etmiştir. İmparatorluk bakiyesi olan Türkiye, gerek Anadolu coğrafyas1nın güzergâh olma özellikleri, gerek Osmanlı sonrası kurulan ulus-devlet yapılarındaki homojen nüfus arzusundan doğan zorunlu göçler ile gerekse de kendi nüfus politikaları çerçevesinde önemli bir göç rotası olmuştur. Gelişim süreçleri politika yapıcılar tarafından yakından gözlemlenmekle birlikte; 1989 Bulgaristan, 1991 Irak ve 2011 sonras1 Suriye kökenli göç hareketleri tahmin edilenden büyük yoğunluklar içermişlerdir. Bahsi geçen kitlesel yönelimler, Türkiye'nin politika yapıcıları ve kamuoyu bileşenleri tarafindan çeşitli farklılıklar ve benzerlikler çerçevesinde ele alınmışlardır. Çalışma içerisinde öncelikli olarak Türk göç hukuku ve mevzuat irdelenmiş ve Türkiye'ye yönelen kitlesel akınlara ilişkin bir değerlendirmede bulunmadan önce, toplumsal bellekte nasıl bir göç yönetimi ve algısı bulunduğu anlatılmaya çalışılmıştır. Takiben uluslararası göç literatüründen hareketle göç kabul süreçlerindeki belirleyici etmenler kuramsal perspektif çerçevesinde tartışılmıştır. Peşi sıra kronolojik bir yaklaşım ile 1989, 1991 ve 2011 sonrası kitlesel göç yönelimleri, gelişim süreçleri ve Türkiye'deki kabul mekanizmaları üzerinden irdelenmiştir. Çalışma; göç literatürü, kabul yaklaşımları ve tarihsel bir inceleme çerçevesinde metodolojik bir araştırma ile ele alınmıştır. Çalışmada arşiv araştırması ve literatür taraması yöntemlerinden faydalanılmıştır.

\section{Cumhuriyet Dönemi Türk Göç Hukukuna Bir Bakış}

Ulus-devlet kuruluş süreci ve Atatürk döneminde izlenen iskân politikası temelde iki hedef çerçevesinde gelişim göstermiştir. Hedeflerinden ilki dünyadaki örneklere benzer bir yönelim ile ulus-devlet anlayışına uygun olarak homojen toplum oluşturma istemi çerçevesinde vuku bulmuştur. $\mathrm{Bu}$ bağlamda Türk kültürüne bağlı muhacirlerin Türkiye'ye gelmesi teşvik edilmiştir. Türk kültürüne haiz nüfusun artması düşüncesi 
birinci hedefin temel motivasyonu olurken, ikinci hedef iktisadi, askeri ve siyasal gerekçeler çerçevesinde nüfusu arttırmak ve nüfusun yayılışını tanzim etmek olmuştur. ${ }^{1} \mathrm{Bu}$ bağlamda Cumhuriyet döneminde iç iskân uygulamaları da önem arz etmiş ve 1 Ağustos 1926 tarihli İskân Muhtırası kabul edilmiştir. 1926 tarihli uygulama ile devletin kimi grupları kontrol ve denetim altına alma çabaları gözlemlenmiştir. Göçebeler, Çingeneler, sınırlardaki kaçakçı unsurlar ve casuslar, iskân uygulaması çerçevesinde devletin denetim ve kontrolüne almak istediği gruplar olmuştur. ${ }^{2}$

1934 tarihli 2510 sayılı İskân Kanunu, Türkiye’nin göç politikasının 2000'li yıllara dek etkisini sürdüren temel belirleyicileri arasında yer almış ve ülke dış politikasını da yakından etkilemiştir. 1934 tarihli İskân Kanunun 3.maddesi, Türkiye’ye yerleşmek isteyen grupların kabulüne ilişkin bir yönelim belirlemiştir. ${ }^{3}$ Kanun, ulus-devlet anlayış1nın tezahürleri çerçevesinde homojen bir Türk kimliği yaratmak gayreti taşımıştır. Bu bağlamda Türk soy ve kültürüne bağlı göçmen yahut mülteci kabulünü benimserken, bu kimlik tespitini yapmak konusunda İcra Vekilleri Heyeti’ni görevli kılmıştır. Babuş’a göre 1934 İskân Kanunu hazırlığında, Osmanlı dönemi iskân politikasına yönelik eleştirel bir bakış yer bulmuştur. Osmanlı dönemi iskân uygulaması, Türk ırkından olan muhacirlerin bile yerli Türklerle kaynaşmamasına gerekçe vermek ve aşiretlerin otonom yapısının kırılmamasına sebep olmak gibi çeşitli eleştirilere maruz kalmıştır. ${ }^{4}$ Kanun, bahsi geçen Türk soy ve kültürüne bağlı göçmen göçünü teşvik eden bir yönelim izlemiş ve 1923-1997 yılları arasında Yunanistan, Bulgaristan, Yugoslavya ve Romanya' dan Türkiye’ye 1,7 milyon insan göç ederken, 1934 tarihli İskân Kanunun önemli bir teşvik unsuru olduğu not edilmiştir. ${ }^{5}$

Türkiye'ye yakın dönemde yönelim gösteren kitlesel göç hareketlerinin irdelenmesinde, uluslararası göçün bir alt alanı olarak mültecilik hukukunun gelişim sürecinin takip edilmesi önem arz etmektedir. Uluslararası göç bağlamında 1951 Cenevre Sözleşmesi ve tamamlayıcısı nitelikte gelişim gösteren protokoller, göçmenliğin siyasal sebeplerden doğan kısımlarının kurumsallaştırılmasında önem taşımıştır. Bu minvalde mültecilik ve sığınmacılık kavramları, uluslararası ölçekte geniş kabule haiz bir tanım

1 Muhammed Sarı, “Atatürk Dönemi’nin İskân Politikasında İç İskâna Yönelik Çalışmalar”, Hacettepe Üniversitesi Atatürk İlkeleri ve İnklâp Tarihi Enstitüsü Cumhuriyet Tarihi Araştırmaları Dergisi, No: 14, 2011, s. 88-89.

2 Fikret Babuş, Osmanlı'dan Günümüze Etnik-Sosyal Politikalar Çerçevesinde Türkiye'de Göç ve İskân Siyaseti ve Uygulamaları, İstanbul, Ozan Yayıncılık, 2006, s. 133.

3 T. C. Cumhurbaşkanlığı İdari İşler Başkanlığı Hukuk ve Mevzuat Genel Müdürlügü̆, Resmî Gazete, İskân Kanunu, 2733, 7 Teşrinievvel 1336/21 Haziran 1934.

4 Babuş, Etnik-Sosyal Politikalar Çerçevesinde..., s. 177-178.

5 Ahmet İçduygu, Kristen Bielh, “Türkiye’ye Yönelik Göçün Değişen Yörüngesi”, Kentler ve Göç Türkiye, Ittalya, İspanya Örnekleri, ed. Ahmet İçduygu, İstanbul, İstanbul Bilgi Üniversitesi Yayınları, 2012, s. 11-12. 
elde etmişlerdir. "Mültecilerin Hukuki Durumuna İlişkin Cenevre Konvansiyonu”, mülteci ve sığınmacı hukukunun temel direklerinden olmuştur. Kronolojik bir biçimde ele alındığında mültecilerin hukuki durumuna ilişkin sözleşme 28 Temmuz 1951 tarihinde Cenevre'de imzalanarak, 22 Nisan 1954'te yürürlüğe girmiştir. Bu sözleşme, 1967 Ek Protokolü ile düzenlenmiştir. Kronolojinin Türkiye özelindeki gelişiminde ise; bahsi geçen sözleşme 24 Ağustos 1951 tarihinde imzalanmıştır. Takiben 359 Sayılı Onay Kanunu 5 Eylül 1961 tarihli 10898 Sayılı Resmi Gazete'de yayınlanmıştır. Türkiye, sözleşmeyi coğrafi sınırlama şartıyla, ek bir deklarasyonla beraber onaylamıştır. ${ }^{6}$ Türkiye, coğrafi sınırlama şartına göre sadece Avrupa Konseyi üyesi ülkelerden gelen sığınmacıları mülteci olarak kabul edeceğini ilan etmiştir. Avrupa Konseyi üyesi ülkeler dışından gelenler, sığınmacı olarak ele alınmışlardır. ${ }^{7}$ Türkiye, kabul etmiş bulunduğu 1967 ek protokolü çerçevesinde mülteci kabulünde zaman çekincesini kaldırmış, buna mukabil mülteci kabulündeki coğrafi çekince şartı korunmuştur. ${ }^{8}$

1994 tarihli “Türkiye’ye İltica Eden veya Başka Bir Ülkeye İltica Etmek Üzere Türkiye'den İkamet İzni Talep Eden Münferit Yabancılar İle Topluca Sığınma Amacıyla Sinırlarımıza Gelen Yabancılara ve Olabilecek Nüfus Hareketlerine Uygulanacak Usul ve Esaslar Hakkında Yönetmelik" metninde coğrafi çekince şartı korunmuştur. ${ }^{9}$

1934 tarihli İskân Kanunu, Cenevre Sözleşmesi ve 1967 Ek Protokolü, 1994 tarihli İltica Yönetmeliği ve 2006 yılında kabul edilen yeni İskân Kanunu, Türk göç hukukunun temel taşları olmuştur. Türk göç hukukunun yakın tarihli kritik değişim evresi ise 2013 yılında hayata geçirilmiştir. 11 Nisan 2013 tarihinde göç sorunlarının çağın gereksinimleri çerçevesinde daha verimli ele alınabilmesi amacıyla 6458 sayılı Yabancılar ve Uluslararası Koruma Kanunu çıkarılmıştır. Yasa çerçevesinde Göç İdaresi Genel Müdürlüğü (GİGM) kurulmuştur. ${ }^{10}$ Yeni yasal düzenlemede, coğrafi çekince şartı korunarak Avrupa'dan gelenler için mültecilik tanımı devam etmiştir. Öte yandan göç hukukunda yer alan sı̆̆ınmacı ifadesi yerine"şartlı mülteci" terimi getirilmiştir. "İkincil koruma" ve "geçici koruma" kavramları göç düzenlenmesinde yer bulmuştur. Kitlesel göç hareketleri hususunda ise geçici koruma statüsü ön plana çıkmıştır. ${ }^{11}$

6 T.B.M.M. İnsan Haklarını İnceleme Komisyonu Mülteci Hakları Alt Komisyonu, Göç ve Uyum Raporu, 26. Dönem 3. Yasama Y111/ Mart 2018.

7 M. Murat Erdoğan, Türkiye 'deki Suriyeliler, İstanbul, İstanbul Bilgi Üniversitesi Yayınları, 2018, s. 44-45.

8 Sema Erder, Zorla Yerleştirmeden Yerinden Etmeye, İstanbul, İletişim Yayınları, 2018, s. 164.

9 M. Murat Erdoğan, Türkiye'deki Suriyeliler..., s. 47.

10 T. C. Cumhurbaşkanlığ İdari İşler Başkanlığı Hukuk ve Mevzuat Genel Müdürlüğü, Resmî Gazete, Yabancılar ve Uluslararası Koruma Kanunu, 28615, 11 Nisan 2013.

11 M. Murat Erdoğan, Türkiye'deki Suriyeliler..., s. 51-52. 
Suriyelilerin varlığına ilişkin çıkarılan ilk yasal düzenleme İçişleri Bakanlığınca 30 Mart 2012 tarihinde yayınlanmıştır. Bakanlık tarafından bahsi geçen tarihte Türkiye'ye Toplu Sığınma Amacıyla Gelen Suriye Arap Cumhuriyeti Vatandaşlarının ve Suriye Arap Cumhuriyeti'nde Ikamet Eden Vatansız Kişilerin Kabulüne ve Barındırılmasına İlişkin Yönerge yayınlanmıştır. 2014 yılının Ekim ayında ise Geçici Koruma Yönetmeliği yürürlüğe girmiştir. 22 Ekim 2014 tarihinde yayımlanan Geçici Koruma Yönetmeliği Suriye Arap Cumhuriyeti Vatandaşlarının statülerini ele alan bir hukuksal metin olmuştur. ${ }^{12}$

\section{Kabul Süreçlerinde Etkili Olan Faktörler}

Göçmenlerin göç ettikleri ülkedeki kabul ve uyum süreçleri; hukuki, ekonomik, "sosyo-kültürel” olmak üzere üç temel kategori çerçevesinde ele alınabilmektedir. Hukuki uyum süreci, göçmenlerin göç ettikleri ülkede yasal biçimde yaşamlarını sürdürebilmeleri ve göç ettikleri ülke vatandaşlarının yasal haklarına sahip olma olarak irdelenebilecektir. Ekonomik uyum süreci ile yeni bir ülkeye göç yolu ile gelmiş bulunan göçmenlerin kendi bireysel gereksinimleri ve ailesel yaşantılarını sürdürebilecek gelir getirici bir iş sahibi olmalarını içermektedir. Sosyo-kültürel başlıklı üçüncü uyum süreci ile yeni ülkeye göç eden bireylerin, ayrımcılığa maruz kalmadan, kurulu düzen içindeki kültürel ve sosyal yapı ile sağlıklı bağ kurmalarını ifade edilmektedir. ${ }^{13}$ Bahsi geçen uyum kategorileri, toplumsal kabul alanları ile bağlantılı biçimde yorumlanabilecektir. Göçmen grupların göç etmiş oldukları ülkelerdeki kabul süreçlerinde; devletlerin göçten beklentileri, uluslararası sözleşmeler, ekonomik dengeler, toplumsal bellek, toplumsal bellekle bir arada ele alınabilecek bir mahiyet ile öncül göçmen grupların varlığ1, siyasal endişeler, sosyal uyum konusundaki kuşkular başlıca faktörler olarak sivrilmektedir. Bu bağlamda bir irdeleme ile Portes ve Rumbaut'un kabul sürecinde, göç alan ülke bileşenlerinin yönelimlerinin önem arz ettiği gözlemleri ön plana çıkmıştır. Portes ve Rumbaut, devletin göçü reddetme eğiliminde olabileceği, aktif yahut pasif kabul biçimlerinde, ülkeye yönelen göçe ilişkin karar mekanizmasında etkin olabileceği analizini yapmışlardır. İkilinin analizine göre devlete ek olarak göç alan ülke nüfusun ve ülkenin emek piyasasında söz sahibi olan kesimin yönelimleri ve menşe bölgeden daha önce göç etmiş insanların varlı̆̆ı göçün kabulüne ilişkin süreçte etkili

12 T. C. Cumhurbaşkanlığı İdari İşler Başkanlığı Hukuk ve Mevzuat Genel Müdürlüğü, Resmî Gazete, Geçici Koruma Yönetmeliği, 29153, 22 Ekim 2014.

13 Alexandra Fielden, Local Integration: an Under-Reported Solution to Protracted Refugee Situation, Geneva, UNHCR, 2008, s. 2-3. 
faktörler olarak ön plana çıkmaktadır. ${ }^{14}$ Portes ve Böröcz'ün, ülkelerin göçmen kitlelere ilişkin yaklaşımları üç kategori çerçevesinde ele alınabilmektedir. İlk yaklaşımda devlet, ülkeye yönelen göç akımına karşı olumsuz bir tutum geliştirmektedir. Bu yaklaşımın ön plana çıkması göçmen grupları kırılgan yapmakta, sermaye sahibi kesimlerce onlara ilişkin geliştirilen yaklaşım vasıfsız işçilik çerçevesinde seyretmektedir. İkinci kategoride göç, kabul alan devlet mekanizması tarafından onay almakla birlikte aktif destek görmemektedir. Bu bağlamda göçmen grubu teşkil eden fertlerin şahsi hünerleri toplumsal kabulde özel önem arz etmektedir. Üçüncü kategoride ise ülke kamuoyu bileşenlerince ekseri olarak göçmen gruba yönelik olumlu bir tutum gözlemlenmektedir. Bahsi geçen olumlu tutum devlet mekanizmasının göçmen gruplara yönelik aktif desteği çerçevesinde vücut bulabilmekte ve ekonomik imkânlar ile yasal haklar ve sosyal kolaylıklar göçmen gruplar için hazır hale getirilmektedir. ${ }^{15}$ Göç kabul süreçlerinde k1sıtlayıcı görüşler iki temel gerekçe çerçevesinde ele alınabilmektedir. Bu bağlamda ilk gerekçe ekonomik gerçeklikler olmaktadır. Az gelişmiş ülkelerden gelen göçmenlerin, hedef ülkedeki yerli işçilerin ücretlerini aşağ 1 çektikleri görüşü ekonomik gerekçenin temelini oluşturmaktadır. İkinci gerekçe ise kültürel ve kimliksel değerlerin muhafazas1 noktasında gelişmektedir. ${ }^{16}$ Hedef ülkedeki yerleşikler, fazla olarak ele alınabilecek sayıdaki göçmenlerin ülkelerindeki kültürel öğelere ve kimlik değerlerine zarar verebileceği çekinceleri yaşamaktadır. ${ }^{17}$

\section{2.a. Bulgaristan Merkezli 1989 Kitlesel Göç Hareketi}

Bulgaristan'dan Türkiye coğrafyasına yönelik beş büyük kitlesel göç hareketi gözlemlenmiştir. 1877-1878 Osmanl1-Rus Savaşı ilk kitlesel göç akınına sahne olmuştur. 1912-1913 Balkan Savaşı göçü, 1925 tarihli Türk-Bulgar İkamet Sözleşmesi'ne dayanan göçler ve 1950-1951 göç hareketleri, çalışmanın içeriği bağlamında ele alınacak olan 1989 tarihli kitlesel göç hareketinden önceki yoğun ölçekli nüfus hareketleri olarak kaydedilmiştir. ${ }^{18}$

14 Alejandro Portes ve Ruben G. Rumbaut, Immigrant America: A Potrait. California,University of California Press, 1990, s. 56, 84, 85'den aktaran Nihan Ciğerci, Bursa-Kırcaali Hattı: 1989'da Gelen Bulgaristan Göçmenleri Örneği, ed. S. Gülfer Ihlamur Öner, N. Aslı Şirin Öner, İstanbul, İletişim Yayınları, 2016, s. 112.

15 Alejandro Portes ve Jozsef Böröcz, "Contemporary Immigration: Theoretical Perspectives on its Determinants and Modes of Incorporation”, International Migration Review, C. XXIII, No: 3 (1987), s. 618-619.

16 David Bartram, Marista V. Poros ve Pierre Monforte, Göç Meselesinde Temel Kavramlar, çev. Itır Ağabeyoğlu Tuncay, Ankara, Hece Yayınları, 2017, s. 254.

17 Nathan Glazer, “The closing door”, Arguing Immigration: Are New Immigrants a Wealth of Diversity...or a Crushing Burden?, ed. Nicolaus Mills, New York, Simon\&Schuster, 1994, s. 37-47.

18 İbrahim Yıldız, Türkiye’ye Uluslararası Göçler ve Türkiye’nin Göç Politikası, Ankara, Kırmızı Çatı Yayınları, 2018, s. 29-30. 
1913 yılında Osmanlı ve Bulgaristan devletlerinin yöneticileri arasında bir mübadele anlaşması imzalanmış ve anlaşma çerçevesinde ortak sınır bölgesinden 15 kilometrelik bir bölgedeki toplam 90 bin civarındaki Bulgar ve Müslüman gönüllülük esası çerçevesinde yer değiştirmiştir. Mübadele anlaşması çerçevesinde göç edenlerin bazı haklarının karşılıklı biçimde korunması temel alınmıştır. ${ }^{19} 1950$ ve 1952 yılları arasında Türkiye'nin Kore Savaşı'na katılım göstermesi ve NATO’ya üyelik süreci neticesinde, Türkiye ile farklı ideolojik eksende yer alan Bulgaristan, 150.000'i aşkın Türk’ü sınır dışı ederek Türkiye'ye göndermiştir. 1968 yılında iki ülke arasında "Yakın Akraba Göçü” anlaşması imzalanmıştır. ${ }^{20} 1970$ 'li yıllarda aile birleşimleri çerçevesinde 110.000 civarında Türk, Türkiye'ye göç etmiştir. ${ }^{21}$

Bulgaristan’daki Müslüman Türkler, 1984 yılı Aralık ayı ve 1985 yılı Mart ayları arasında yoğun bir tazyikle karşı karşıya kalmışlardır. Dil yasağ1, zorla isim değiştirme ve Türklere yönelik katliamlar sürecin öne çıkan eylemleri olmuştur. ${ }^{22} 1984$ yılında Jivkov’un iktidara gelmesini takiben güç kazanan, Türklüğe dair hiçbir unsurun görünür kılınmaması temelindeki asimilasyon politikalarının ideolojik ekseninde, Müslümanlığın Osmanlı döneminde zorla kabul ettirilmiş olduğu iddiaları gözlemlenmiştir. Türkiye'nin Bulgaristan'da hayatlarını idame eden Türkleri ilerleyen süreçlerde Bulgar devleti aleyhinde kullanabilecekleri inancı ve Türklerin doğum oranlarının Bulgarları geride bırakması uygulanan baskıda önemli rol oynamıştır. ${ }^{23}$ Bulgar ordusu içerisinde \%30'lara ulaşan Türk ve Müslüman nüfusun, muharip birlikler olarak savaş ekseninde eğitilmemeleri demografik yapı ve etnik güvensizlik noktasında dikkat çekici bir örnek olmuştur. ${ }^{24}$

Kökleri Fransız devrimine dayanan yurttaşlık modelinin, ulusu aynı topraklar üzerinde yaşayan ve ortak millî duygu ve ortak kültürü paylaşan yurttaşlar bütünü penceresinde ele alma anlayışı sosyalist dönemdeki Bulgaristan hükümetlerinde de kendisini göstermiştir. Bulgaristan'daki politika yapıcıları, Bulgaristan'da yaşayan tüm Müslüman

19 Selahattin Önder, 1913 Türk-Bulgar Mübadelesi, Yeni Türkiye, No: 31 (2000), s. 342-346'dan aktaran Elçin Macar, Yunanistan'dan Anadolu'ya Göç: Nüfus Mübadelesi, ed. M. Murat Erdoğan, Ayhan Kaya, İstanbul, İstanbul Bilgi Üniversitesi Yayınları, 2015, s. 174; Sema Erder, Zorla Yerleştirmeden..., s. 81.

20 Elçin Macar, Yunanistan'dan Anadolu'ya..., s. 175.

21 Kemal Kirşçi ve Sema Karaca, "Hoşgörü ve Çelişkiler: 1989, 1991 ve 2011'de Türkiye'ye Yönelen Kitlesel Mülteci Akınları”, Türkiye'nin Göç Tarihi, ed. M. Murat Erdoğan, Ayhan Kaya, İstanbul, İstanbul Bilgi Üniversitesi Yayınları, 2015, s. 301.

22 İbrahim Yıldız, Türkiye'ye Uluslararası Göçler..., s. 36.

23 Kemal Karpat, Osmanlı 'dan Günümüze Etnik Yapılanma ve Göçler, İstanbul, Timaş Yayınları, 2017, s. 416, 423; Sema Erder, Zorla Yerleştirmeden ..., s. 178.

24 Kemal Karpat, Osmanlı'dan Günümüze..., s. 430. 
ve Türk azınlık mensuplarını ortak devlet, ortak toprak, ortak yurttaşlık bağı ile Bulgaristan'a bağlı olarak ele almışlardır. Rejim, bu minvalde Bulgaristan'daki Türklerin tümünün Bulgar olarak kabul edilmesi görüşünü resmi tez olarak benimsemiştir. Dolayısıyla ulusal kimlik ve vatandaşlık aidiyeti ön plana çıkarılıp, etnik ve dinsel aidiyet görmezden gelinerek soyut ve homojen bir sosyalist ulus yaratılması amaçlanmıştır. ${ }^{25}$ Türklerin ad ve soyadları 1984-1985 yılları arasında kitlesel olarak zorla değiştirildikten sonra, Türk kültürünün izleri Bulgaristan'da ortadan kaldırılmaya başlanmıştır. Bulgaristan Türklerinin zorla asimile edilmeye çalışıldığı bu dönemde Bulgaristan yönetimi, süreci hızlandırmak amacıyla dayatılan etnik homojenleştirme politikalarına öncelik vermiştir. Dolayısıyla 1984-1989 dönemi Bulgaristan Türklerinin kitlesel ve etnik olarak topyekûn asimile edilmek istenildiği, ad ve soyadlarının zorla değiştirildiği ve Bulgarlaştırmanın tüm Türklere dayatıldığı bir süreç olmuştur. Bu durum Bulgaristan'daki Türklerin ilerleyen süreçte Türkiye'ye göç eğilimlerinin gelişiminde etkili olmuş ve dil, din, yaşam hürriyeti beklentisi, gelişecek göç hareketinin temel motivasyonları arasında yer almıştır. ${ }^{26}$ Rejim, baskı politikalarının diğer uzantıları olarak Türklerin çeşitli katliamlara tabi tutulmaları ve hapishanelere gönderilmeleri uygulamalarını hayata geçirmiştir. Türkiye kamuoyu gelişmeleri yakından ve endişe ile tepki çekmiştir. Üniversiteler, dernekler, siyasal partiler kınama bildirilerini kaleme almışlardır. İstanbul başta olmak üzere ülke genelinde olaylara ilişkin protesto mitingleri düzenlenmiştir. ${ }^{27}$ Benzeri protestolar Bulgaristan'da da yaşanmıştır. 1989 yılının Mayıs ayında 50.000'den fazla Türk, Şumnu kentinde bir araya gelmiş ve rejimin baskıcı yönelimlerini protesto etmişlerdir. Rejim protestoları silahla bastırma yolunu seçmiştir. ${ }^{28}$

Türkiye ve uluslararası kamuoyunun baskılara yönelik sert tepkileri neticesinde rejim, Türk azınlıktan kurtulmak düşüncesinden hareketle pasaport dağıtmaya başlamıştır. Bulgaristan yönetimi, 1984-1989 yılları arasında Türkiye’ye göç etmek için 500 bine yakın müracaat almıştır. ${ }^{29} 2$ Haziran 1989 tarihinde Todor Jivkov, televizyon ekranlarından Türk azınlığa yönelik yapmış olduğu değerlendirmede "Pasaportlarınızı vereceğiz, Türkiye kapılarını açsın, kalmak istemeyen çekip gitsin" ifadesinde bulunmuştur. ${ }^{30} 1989$ yılında Türkiye, Bulgaristan'dan gelen göçmenlere açık kapı politikası ile vizesiz geçiş serbestîsi getirmiş, gelenlerin sayısının 360 bini aşması sonrası kontrollü geçiş sürecini

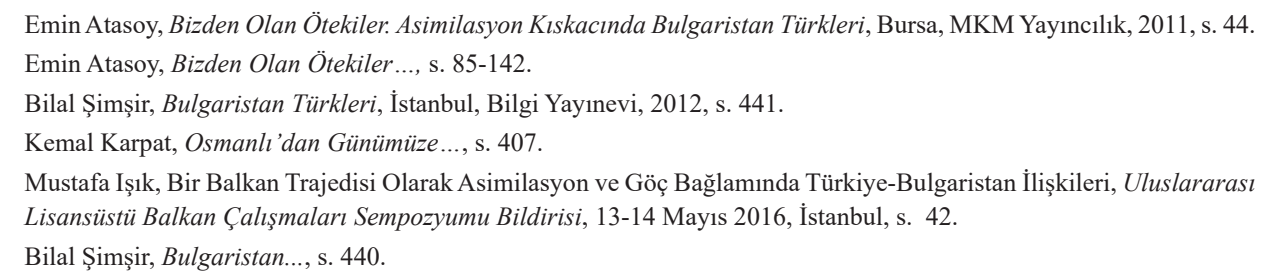


başlatmıştır. 1989 yılının Mayıs ve Ağustos ayları arasında yaşanan zorunlu göç hareketi, İkinci Dünya Savaşı sonrası Avrupa'da meydana gelen en büyük kitlesel sı̆̆ınma hareketlerinden birisi olmuştur. Göçmenlerin sayısı 3 ay gibi kısa bir sürede 360 bin kişiyi aşınca Türkiye sınır kapılarını kapatmış ancak Bulgaristan'dan Türkiye'ye göç süreci devam etmiştir. 1989 Mayıs ayı ile Ağustos arası dönemde 311.862 göçmen Türkiye’ye gelmiş, vize uygulamasının aktif bir hal aldığı Ağustos 1989'dan Mayıs 1990'a kadar ise yeni gelen göçmen sayısı 34.098 kişiye inmiştir. Todor Jivkov'un istifası ile bir yıllık periyotta Bulgaristan'a geri dönen göçmen sayısı ise 133.272 olurken, yaşlı, emekli göçmenler ve engelli dezavantajlı grupların elde etmiş oldukları sosyal güvenlik haklarını yitirmemek için geri dönüş eğiliminde başı çektikleri gözlemlenmiştir. ${ }^{31}$ Türk hükümeti Bulgaristan'dan gelen göçmenleri 1951 Sözleşmesi çerçevesinde mülteci tanımı merkezli olarak değerlendirmemiş ve onları daha 1lımlı bir yaklaşım ile vatandaş olacak göçmenler olarak ele almıştır. İskân Kanunu Ek Madde 33 ile 1 Ocak 1984 sonrası Bulgaristan'dan gelenlerin Türk kültürüne bağlı serbest ya da iskânlı göçmenler olarak kabul edilmesini içerecek şekilde değiştirilmiştir. ${ }^{32}$

Geçici iskân alanlarına sevk edilen göçmenlerin yiyecek, içecek, ibadet alanı sorunları, sağlık hizmeti gereksinimleri ivedi biçimde karşılanmıştır. Göçmenler toplumsal hafızada yer edinmiş marşlarla sınır kapılarında karşılanmıştır. İlgili bakanlıklar ve Kızılay başta olmak üzere kurum ve kuruluşların yoğun çabaları ile göçün olası zorlukları en aza indirilmeye gayret gösterilmiştir. İlerleyen süreçte gıda ve kira yardımının tahsis edilmesi, sürekli yaşam alanlarının tahsisi, mesleki vasıflara uygun iş sahalarına yönlendirilmeleri ve göçmenlerin uyum sürecinin takibi gibi kritik konular, görevli kıl1nan koordinasyondan sorumlu bir Devlet Bakanlığı tarafından idame edilmiştir. ${ }^{33}$ Bulgaristan'dan gelen göç kafileleri, gelenlerin varsa akrabalarının bulunduğu yerlere ücretsiz ulaştırılmıştır. Göçmenlerin köken ülkelerden taşınan paraları, uygun kurlardan Türk parasına çevrilmiştir. İlk ve orta öğrenime başlayan öğrenciler için ailelerine tek seferlik destek ödemeleri sağlanmış, erkek çocuklarının sünnet organizasyonları desteklenmiş ve göçmenlerin vatandaşlığa geçişleri konusundaki çalışmalar hız kazanmıştır. ${ }^{34}$ Türkiye'de siyasal karar mekanizması, Bulgaristan'dan gelen Türklerin kalıcı olarak yerleşmelerini sağlamak amacı çerçevesinde toplu konut projelerine hız vermiştir. $\mathrm{Bu}$

31 Bilal Şimşir, Bulgaristan ..., s. 443-444.

32 Gül Çatır, “Zorunlu Göç Tecrübesinin Devlet Politikalarındaki Yansıması: Bulgaristan'dan Türkiye’ye Kitlesel Göçün Analizi”, Küreselleşme Çağında Göç, ed. S. Gülfer Ihlamur Öner, N. Aslı Şirin Öner, İstanbul, İletişim Yayınları, 2016, s. 224.

33 Bilal Şimşir, Bulgaristan ..., s. 444-445.

34 Ercüment Konukman, Belgeler Işı̆ğında Büyük Göçve Anavatan, Ankara, Türk Basın Birliği, 1990, s. 103-105. 
minvalde göçmenlere bir yıl için kira yardımında bulunulmuştur. ${ }^{35}$ Türkiye Cumhuriyeti'nin göçmen Bulgaristan'dan gelen Türklerin entegrasyonu için gösterdiği çabalar arasında Türk ve İslam tarihi hakkındaki kurslar, öğrencilerin devlet okullarına kayd1, üniversitelere geçişlerinin sağlanması ve diplomaların kabulündeki kolaylıklar ön planda yer almıştır. ${ }^{36}$ Bulgaristan'dan gelen Türklere yönelik yardımları arttırmak amacıyla Sosyal Yardımlaşma ve Dayanışma Fonu ile ilgili yasada değişiklik yapılmıştır. Toplumda oluşan duyarlılığa koşut biçimde Maliye Bakanlığı, vatandaşların toplayacağı bağışların vergilerden düşülebileceğini açıklamıştır. ${ }^{37} 1989$ tarihli göç hareketiyle gelen Bulgaristan Türkleri, 1991 yılının ikinci yarısından itibaren Türkiye Cumhuriyeti vatandaşlığına alınmaya başlanmıştır. ${ }^{38}$

Türkiye, Bulgaristan'daki Türklerin durumlarının iyileştirilmesi ve kitlesel göç sürecini takiben göçmenlerin hakları konusunda aktif bir dış politika izlemiştir. Bulgaristan'daki Türklere yönelik artan baskılar nedeniyle Türkiye, Avrupa Konseyi'ne çağrıda bulunmuş ve Türklerin maruz bırakıldıkları sıkıntıların giderilmesi isteğini konsey üyelerinin gündemine getirmiştir. Türkiye'nin yoğun diplomatik faaliyetlerine koşut olarak 50 den fazla ülke ve çeşitli uluslararası işbirliği örgütleri, Bulgaristan'ın azınlık politikalarını ve göç konusundaki tutumunu protesto etmişlerdir. Öte yandan Avrupa'nın Bulgaristan'da yaşanan olaylara tepkisi düşük ölçekte ve geç olarak ele alınabilecek bir biçimde gelişim göstermiştir. ${ }^{39}$ Bulgaristan' dan gelen Türklerin bir bölümünün geri dönüşüne ilişkin Bulgar göç yazımında farklı örnekler gözlemlenmiştir. İlgili yaklaşımda Türkiye'de bir takım itici faktörlerin vücut bulduğu ve barınma, iş gibi konularda yaşanan aksaklıkları geri dönüşte etkili olduğu yaklaşımı ön plana çıkmıştır. ${ }^{40}$ Bulgaristan'daki Türklerin Türkiye'ye yönelik göçü Bulgaristan'daki demografik yapıyı önemli ölçüde etkilediğini belirten Vasileva, oturma ve çalışma izni almakta zorlanan Bulgaristan Türklerinin güvenceli ve kalıcı işler bulamadıklarına dikkat çekmiştir. Vasileva'ya göre farklı bir siyasal, sosyal, ekonomik gerçekliğin olduğu Bulgaristan' dan, Türkiye'ye gelmiş olmak dışlanma sebepleri arasında yer almıştır. ${ }^{41}$

35 Bilal Şimşir, Bulgaristan ..., s. 448-454.

36 Ercüment Konukman, Belgeler Işı̆̆ııda..., s. 120-121.

37 Gül Çatır, "Zorunlu Göç...”, s. 224-225.

38 Kader Özlem, “Türkiye'nin Balkan Türkleri Politikasının Analizi (1991-2014)”, Trakya Üniversitesi Sosyal Bilimler Enstitüsü Uluslararası İlişkiler Anabilim Dalı, Yayınlanmamış Doktora Tezi, Edirne, 2015, s. 141.

39 Bilal Şimşir, Bulgaristan..., s. 441-442.

40 Sema Erder, Zorla Yerleştirmeden ..., s. 180.

41 DarinaVasileva, "Bulgarian Turkish Emigration and Return", International Migration Review, C. XXVI, No: 2 (1992), s. $348-349$. 


\section{2.b. Irak Merkezli 1991 Kitlesel Göç Hareketi}

1988-1991 yılları arasında Irak’tan Türkiye'ye yönelik üç kitlesel göç hareketi yaşanmıştır. Bunlar; İran-Irak savaşı esnasında yaşanan göçler ve Körfez Savaş1 esnasında Irak ve Kuveyt'ten geçici iş̧̧i tahliyesine ek olarak, çalışmanın odağında yer alan büyük kitlesel göç hareketi ise 1991 yllı Nisan ayında vuku bulmuştur. Irak'ın kuzeyinde yaşayan Kürtlerin ayaklanmaları ve takiben bazı şehirlerde idareyi ele almalarını takiben Irak Ordusu sivilleri de kapsayan kanlı bir harekât başlatmıştır. 2-11 Nisan 1991 tarihleri arasında Türkiye'ye kitlesel göç çerçevesinde büyük bir yönelim gerçekleşmiş̧ir. ${ }^{42}$ Nisan 1991 'de çoğunluğunu Kürtlerin oluşturduğu, aralarında Arap, Keldani, Nasturi, Türkmen ve Süryani grupların da bulunduğu 467.489 Irak vatandaşı, Türkiye ve Irak arasındaki dağlık bölgeden Türkiye'ye giriş yapmıştır. ${ }^{43}$ Türkiye, cumhuriyet tarihinde ilk kez çoğunluğu Türk ve Müslüman olmayan, farklı etnik ve dini kökene mensup grupların göç akışını yaşamıştır. ${ }^{44}$

Türkiye, PKK terörü ile yürütmüş olduğu mücadele ve sınır güvenliği endişelerinden dolayı sürecin başında sınır kapılarını açmak noktasında isteksiz bir yönelim sergilemiştir. 1991 yılında gerçekleşen kitlesel sığınma hareketi güvenlik bürokrasisi tarafından Türkiye'nin ulusal güvenliği açısından tehdit unsuru olarak algılanmıştır. Türkiye ve Irak sınırına sığınmacıların barınması için kurulması planlanan kampların "Gazze şeridi" ile benzerlik göstereceğinden endişelenilmiş ve hükümet, sınırların kapatılarak sığınmacıların Türkiye'ye geçişini engelleme kararı vermiştir. Öte yandan ağır mevsimsel şartlar ve yaşanan insani kriz ile Türkiye'nin yönelimleri, uluslararası kamuoyu ve Türkiye kamuoyu bileşenlerince eleştirilere maruz kalmıştır. ${ }^{45}$ Türkiye'nin konuyla ilgili olarak uluslararası politikada attığı ilk adım; Kürtlere yönelik saldırgan bir tutum izleyen Bağdat yönetimine karşı Birleşmiş Milletler Güvenlik Konseyi’ni (BMGK) harekete geçirmek doğrultusunda olmuştur. Ancak özellikle Kürt sığınmacıların Türkiye içerisinde aile ve akrabalık bağı olan yakınlarının bulunması Türkiye'de politika yapıcıların üzerinde sınırların açılması ve sığınmacılara gerekli yardımların yapılması konusunda bir iç baskı yaratmıştır. ${ }^{46}$ Türkiye, Cumhurbaşkanı Turgut Özal'ın eğilimleri çerçevesinde Irak'ın Kuzeyinde güvenli bir bölge oluşturulması fikrini savunmuş ve bu fikrin hayata geçirilmesi adına diplomatik girişimlerde bulunmuştur. 36. Paralel ile

42 İbrahim Yıldız, Türkiye'ye Uluslararası Göçler..., s. 55-59.

43 T.C. İçişleri Bakanlığı Göç İdaresi Genel Müdürlüğü, Kitlesel Akınlar, 2 Şubat 2015; İbrahim Yıldız, Türkiye’ye Uluslararası Göçler..., s. 56.

44 Ahmet İçduygu ve Damla B. Aksel, “Turkish Migration Policies: A Critical Historical Retrospective”, Perceptions, C. XVIII, No: 3 (2013), s. 167.

45 Kemal Kirişçi ve Sema Karaca, "Hoşgörü ve Çelişkiler:...”, s. 298, 305.

46 Kemal Kirişçi ve Sema Karaca, "Hoşgörü ve Çelişkiler:...”, s. 298, 305. 
Türkiye arasında kalan bölgede oluşturulan güvenli bölge, kitlesel sığınma çerçevesinde Türkiye'ye gelen sığınmacıların çoğunluğunun yerleştirildiği bir alan olmuştur. ${ }^{47}$

Sığınmacılar, Irak askeri birliklerine yakalanmamak için Türkiye'ye genel olarak gece saatlerinde ve dağlık bölgelerden geçerek ulaşmışlardır. Açlık, susuzluk, yorgunluk ve hastalıkla boğuşan, yeme-içme, sağlık ve barınma merkezli temel ihtiyaçlar çerçevesinde zor durumda olan sığınmacılara ilk yardımı görevli bulunan Türk askeri ve bölge halkı yapmıştır. Zorlu şartlar altında Türkiye'ye giriş yapan sığınmacılar daha ziyade Hakkâri ve Şırnak’ın çeşitli noktalarında gelişigüzel konaklamışlardır. ${ }^{48}$

Sığınmacıların Türkiye’ye gelmeye başlamasıyla birlikte ülke genelinde çeşitli yardım kampanyaları düzenlenmiştir. Kızılay başta olmak üzere resmi kurumlar sürece müdahil olmuştur. Hem inanç temelli çeşitli sivil toplum kuruluşları aracılığıyla hem de bireysel olarak sığınmacılara ilk günlerden itibaren ayni ve nakdi yardımlarda bulunulmuştur. BM başta olmak üzere uluslararası kuruluşların ve dünya devletlerinin yardımları bir takvime bağlanmış ve uluslararası yardımlar sığınmacılara ilk 10 günden sonra ulaşmaya başlamıştır. Bu süre içerisinde sığınmacılar devletin ve vatandaşların yardımları ile yaralarını sarabilmiştir. ${ }^{49}$

Başlangıçta sayıları 20’yi bulan geçici kamplara yerleştirilen sı̆̆ınmacılar, atılan diplomatik adımlar sayesinde evlerine güvenli bir biçimde dönmeye başlamıştır. 1991 yılı Mayıs ayı itibariyle Türkiye'deki sığınmacı sayısı 14.000'e kadar düşmüştür. Türkiye'de kalan sığınmacılar önce kamplara yerleştirilip daha sonra resmi mülteci statüsü ile üçüncü ülkelere gönderilmiştir. ${ }^{50}$

Türkiye'nin girişimleri ile oluşturulan güvenli bölgeye sığınmacıların büyük bölümünün gönderilmesiyle 20 Ağustos 1991 tarihi itibariyle Türkiye'de 5.274 Iraklı sığınmacı kalmış ve kalan sığınmacılar da Sivas-Kangal'daki Türkiye Kömür İşletmeleri Tesislerine, Tatvan Mülteci Misafirhanesine, Kayseri-Kuşçu Geçici Toplanma ve Yerleşim Merkezine ve Silopi Hac Konaklama Tesisleri kamplarına yerleştirilmiştir. Hakkâri ve Şırnak bölgesinde yoğunlaşan sığınmacıların bölge ekonomisi üzerinde olumsuz etki oluşturduğu iddiaları ile şahıs ve kamu mallarına yönelik gelişen bazı tahribatlar, kitlesel sığınma hareketinin kamuoyunda tartışma yaratan bir başka boyutu olmuştur. ${ }^{51}$

\footnotetext{
47 İbrahim Yıldız, Türkiye'ye Uluslararası Göçler..., s. 59.

48 Muhteşem Kaynak, Iraklı Sığınmacılar ve Türkiye, İstanbul, Tanmak Yayınları, 1992, s. 115-116.

49 Muhteşem Kaynak, Iraklı Siğınmacılar..., s. 118, 121.

50 Kemal Kirişçi ve Sema Karaca, "Hoşgörü ve Çelişsiler:...", s. 305.

51 Muhteşem Kaynak, Iraklı Sı̆̆ınmacılar..., s. 73, 90.
} 


\section{2.c. 2011 Sonrası Suriye Kökenli Kitlesel Göç Hareketi}

Suriye'de yaşanan toplumsal kriz ve iç savaş atmosferi, Arap Baharı süreci çerçevesinde ele alınabilecek bir olay olarak ön plana çıkmıştır. Arap Baharı olayları 17 Aralık 2010 tarihinde Tunus'ta yaşanan gelişmeler sonucu ortaya çıkmıştır. Tunus'ta Muhammed Buazizi isimli bir tezgâhtarın satış tezgâhına el konulmuştur. Olayı protesto etmek isteyen Buazizi'nin intihar eylemi ile Tunus'ta başlayan olaylar silsilesi pek çok ülkede önemli yankılar uyandırmış ve uluslararası terminolojide Arap Baharı olarak anılmıştır. Tunus, Mısır, Libya ve kimi diğer ülkelerde etkileri gözlemlenen toplumsal olaylar, 2011 yılında Suriye'nin öncelikli gündemi olmuştur. ${ }^{52}$

Suriye'de şiddetin olağan bir hal alması neticesinde sınır ötesi insan hareketlilikleri yoğunluklu olarak Lübnan, Ürdün ve Türkiye istikametlerinde gelişmeye başlamıştır. Suriye'den Türkiye'ye yönelik ilk sınır ötesi göç hareketliliği 29 Nisan 2011 tarihinde yaşanmıştır. Suriye'deki şiddet olayları neticesinde, can ve mal kaygısı çerçevesinde Cilvegözü sınır kapısından Türkiye'ye giriş yapan 252 kişilik ilk Suriyeli grup, Hatay'daki bir spor salonunda misafir edilmiştir. Gruba geçici konaklama ve gida ihtiyaçları sağlanmıştır. ${ }^{53}$ Grup, Yayladağı bölgesindeki çadır kent alanına yerleştirilmiştir. 2011 yılının Haziran ayında ise Altınözü ve Boynuyoğun çadır kentleri inşa edilmiştir. Yaşanan uluslararası göç hareketi ile ilgilenilmesi için T.C Başbakanlık Afet ve Acil Durum Başkanlığı (AFAD) ve Türk Kızılayı görevlendirilmiştir. ${ }^{54}$

2011 yılının Nisan ayından başlayarak Suriye'den girişlere açık kapı politikası çerçevesinde izin verilmiş, Ekim ayına dek 8 adet kamp hizmete açılmış ve gelenlerin dini kimlikleri üzerinden bir kabul referansını tanzim edilmiştir. Sınır ötesi nüfus hareketliliğinin başlangıcı itibariyle Türkiye ve Suriye arasındaki diplomatik ilişkiler devam etmiştir. Ancak dönemin Başbakanı Erdoğan ve Dışişleri Bakanı Davutoğlu'nun bekledikleri reform paketi Esad tarafından kabul edilmemiş ve iki ülke arasındaki ilişkiler hızlı bir bozulma sürecine girmiştir. Türk kamuoyunun bir bölümü ve Türkiye politika yapıcılarındaki genel kanaat, Esad rejiminin yaşanan toplumsal krize uzun bir süre direnemeyeceği istikametinde vücut bulmuştur. ${ }^{55}$

52 “Suriye'de içsavaş 3'üncü yılında", Hürriyet, 15 Mart 2013.

53 T.C. İçişleri Bakanlığı Göç İdaresi Genel Müdürlüğü, Türkiye’de Geçici Koruma, 22 Aralık 2015, https://www.goc.gov. tr/icerik3/turkiye\%E2\%80\%99de-gecici-koruma_409_558_1097, Erişim Tarihi: 19 Ocak 2019.

54 M. Murat Erdoğan, Türkiye'deki Suriyeliler, s. 7.

55 Kemal Kirişçi ve Sema Karaca, "Hoşgörü ve Çelişkiler:...”, s. 306-308. 
2011 yılında başlayan ilk göç hareketliliğini takiben, 2012 yılında kayıt altına alınan Suriyeli sayısı 14.237 olmuştur. Dışişleri Bakanı Ahmet Davutoğlu, 2012 yılının Ağustos ayında göç sürecinin gelişim aşamasında konu özelinde gerçekleştirmiş olduğu değerlendirmede; Türkiye'deki Suriyeli sayısının 100.000'i aşması durumunda, olayın mülteci krizinin ötesinde bir kitlesel sığınma anlamına geleceğini belirtmiştir. Bahsi geçen açıklama ve kimi politik yönelimler Türkiye için 100.000 sayısının beklentinin üst seviyesi olduğu izlenimini doğurmuştur. ${ }^{56}$ Öte yandan göç eden Suriyeliler kısa bir süre içerisinde beklentilerin çok üzerine çıkmış ve 2013 yılında kayıt altındaki Suriyeli sayıS1 224.655 olmuştur. 28 Mart 2019 tarihinde açıklanan son verilere göre Türkiye'deki Geçici Koruma Altındaki Suriyeli sayısı 3.641.344'e ulaşmıştır. ${ }^{57}$ Cumhuriyetin ilanından 2005 yılına kadar uzanan 82 senelik zaman zarfında, Türkiye’ye 1,7 milyon dolayında göçmen gelmiştir. ${ }^{58}$ Buna karşın ülkeye yönelik ilk Suriyeli göçünü takiben yaklaşık 8 senelik bir zaman zarfında 4 milyona yaklaşan bir göç hareketi ile karşılaşılmış olması, Türkiye'nin karşılamış olduğu göç hareketinin mahiyeti hakkında dikkat çekici bir özellik oluşturmuştur.

Türk göç hukukunun ele alındığı başlıkta tartışılmış olduğu üzere göç sürecini takiben, 2012 tarihli yönerge ilk resmi metin olma özelliği taşımıştır. 22 Ekim 2014 tarihli Geçici Koruma Yönetmeliği yine süreç içerisinde Suriyelilerin Türkiye'deki hukuki durumlarının ele alınmasında önem arz etmiştir. Bir süre için "misafir" olarak tanımlanan Türkiye'deki Suriyelilerin Geçici Koruma statüsü YUKK 91. madde ve 22 Ekim 2014 tarihli Geçici Koruma Yönetmeliği ile düzenlenmiştir. İlgili düzenleme çerçevesinde Türkiye'deki kayıt altındaki Suriyeliler geçici koruma statüsüne alınmıştır. Geçici koruma kapsamında; sağlık, iş, eğitim, sosyal yardım, evlilik gibi kimi haklar ilgili gruplara tahsis edilmektedir. ${ }^{59}$

Ülke kamuoyunda göç sürecine ilişkin kimi endişeler vuku bulmuştur. Suriyelilerin kitlesel sığınmaları esnasında yasa dışı örgüt mensuplarının sınırdan sızmış olduğuna ilişkin inanç bu minvalde ön plana çıkmıştır. Güvenlik algısı konusunda endişe yaratan öncül olaylardan birisi Reyhanlı'da meydana gelen saldırılar olmuştur. 11 Mayıs 2013 tarihli Hatay’ın Reyhanlı ilçesinde bombalı saldırılar gerçekleşmiş ve hükümet yetkilileri ilk değerlendirmelerinde olayın Suriye'deki rejim ile ilişkili kişilerce hayata

56 "Suriyeli sayısı 100 bini geçerse...", Sabah, 20 Ağustos 2012.

57 T.C. İçişleri Bakanlığı Göç İdaresi Genel Müdürlüğü, Göç İstatistikleri, Geçici Koruma, 3 Nisan 2019, https://www. goc.gov.tr/icerik3/gecici-koruma_363_378_4713, Erişim Tarihi: 23 Nisan 2019.

58 İbrahim Yıldız, Türkiye'ye Uluslararası Göçler..., s. 64-65.

59 T.B.M.M. İnsan Haklarını İnceleme Komisyonu Mülteci Hakları Alt Komisyonu, Göç ve Uyum Raporu, 26. Dönem 3. Yasama Y111/ Mart 2018. 
geçirildiğini söylemişlerdir. ${ }^{60}$ Saldırılarda 52 kişinin yaşamanı yitirirken, 146 kişi ise de yaralanmıştır. Olay sonrası Suriyelilerin yaşadıkları bir kampa yönelik saldırı girişimi yaşanmıştır. Başbakan Erdoğan, Suriyelileri “kardeş” olarak değerlendirdiği bir konuşma yapmış ve Suriyelilere yönelik desteğin sürmesi gerektiğini vurgulamıştır. ${ }^{61}$ Peşi sıra Türkiye'de meydana gelen IŞİD ve PKK kaynaklı bazı terör eylemleri de sınır güvenliği eksenli endişeleri beslemeye devam etmiştir.

Göç sürecindeki bir diğer endişe ise muhalefet partileri tarafından dile getirilen vatandaşlık tartışması eksenin gelişim göstermiştir. Suriyelilerin önemli bir bölümünün göçün ilk yılları itibariyle, toplumsal uzlaşı olmaksızın hızlı biçimde vatandaşlığa kabul edilecekleri ve bu bağlamda seçim sonuçları üzerinde etki yaratabilecek bir oy potansiyelinin oluşturulacağı endişesi TBMM gündemine taşınmıştır. Cumhuriyet Halk Partisi (CHP) Hatay milletvekili Refik Eryılmaz, İçişleri Bakanı tarafından yazılı olarak yanıtlanması isteğiyle bir soru önergesi vermiştir. Suriyelilerin kaçının vatandaşlığa alındığı ve yerel ve genel seçimlerde kaç Suriyelinin oy hakkı olacağına ilişkin önerge İçişleri Bakanı Muammer Güler tarafından yanıtlanmıştır. Bakan Güler, 24 Mayıs 2013 itibariyle ülkeye giriş yapan 309 bin 205 Suriye vatandaşından 114 bin 297'sinin Suriye'ye döndüğünü belirtmiştir. Güler, Suriyelilerin oy hakkı konusunu 5901 sayılı Türk Vatandaşlığı Kanunu'na atfen vermiş olduğu yanıtta ele almıştır. Suriyeli sığınmacıların Türk vatandaşlığı kazanmalarının söz konusu olmadığını belirtmiştir. Yanıtta Suriyelilerin seçimlerde oy kullanamayacakları da belirtilmiştir. ${ }^{62}$

Türkiye'nin Suriye'deki olaylara ilişkin uygulamış olduğu açık kapı politikasının bir sonucu olarak kısa süre içerisinde yüksek sayıda bir göçmeni ağırlamış olması bazı sosyal sorunları da beraberinde getirmiştir. Gündelik yaşantısını idame ihtiyacı çerçevesindeki Suriyelilerin bir bölümünün kayıt dışı çalışmaları iş piyasasında önemli bir tartışma konusu oluşturmuştur. Göçten yoğun şekilde etkilenen başta Gaziantep olmak üzere çeşitli şehirlerdeki konut ve kira fiyatlarındaki hızlı artış, gündelik yaşamdaki kültürel farklılıkların sosyal yansımaları ve bazı adli olaylar kamuoyunda yankı uyandırmıştır. Gaziantep, Kahramanmaraş ve Kayseri başta olmak üzere çeşitli şehirlerde Suriyeliler ile yaşanan yerel olaylardan dolayı toplumsal eylemler vücut bulmuş ve göç kabul sürecinde yaşanan bazı sorunlar yakından gözlemlenmiştir. ${ }^{63}$

60 "İçişleri Bakanı Muammer Güler: Saldırganlar tespit edildi", Hürriyet, 12 Mayıs 2013.

61 M. Murat Erdoğan, Türkiye'deki Suriyeliler, s. 78.

62 “Seçimlerde oy kullanacaklar mı?”, Milliyet, 19 Ağustos 2013.

63 İbrahim Yıldız, Türkiye'ye Uluslararası Göçler..., s. 82-85. 
Türkiye'deki Suriyelilere yönelik siyasal partilerin göç politikaları farklılık arz etmiştir.2011'de başlayan göçün 2013 yılından itibaren yoğunluk kazanmasının etkisiyle, Türk siyasetinde öncelikli tartışma sahası 7 Haziran 2015 Genel Seçim süreci olmuştur. Seçim sürecine girilmeden hemen önce, 24 Ağustos 2014'de Başbakan Yardımcısı Beşir Atalay başkanlığındaki göç temalı toplantının neticesinde ilk kez uyum ve birlikte yaşam vurguları ön plana çıkmıştır. Başbakan Yardımcısı Numan Kurtulmuş ise 6 Kasım 2014 tarihinde Suriyelilerin kalıcılığını vurgulayan bir değerlendirmede bulunmuştur. ${ }^{64}$ 7 Haziran 2015 Genel Seçim sürecinde Adalet ve Kalkınma Partisi (AK Parti), Türkiye'deki Suriyeliler konusunda bir vatandaşlık önerisi geliştirmemiştir. Parti, seçim bildirgesinde Türkiye'deki Suriyelilerden "kardeş" ifadesi ile bahsedilmiş, Şam rejiminin şiddet uygulamaları işaret edilmiş ve süreç insani ve vicdani sorumluluklar çerçevesinde değerlendirilmiştir. İlgili değerlendirme, iktidarın sürece ilişkin yaklaşımının temelini oluşturmuştur. CHP'nin konu özelindeki yaklaşımında, iktidar partisinin dış politikadaki hatalarına koşut bir mahiyet ile göç konusunu ele aldığı gözlemlenmiştir. Bir dış politika başarısızlığı olarak konuyu ele alan CHP, Türkiye'deki Suriyelilerin, barışın hızlı bir biçimde tahsis edilmesi ile acilen ülkelerine gönderilmeleri gerektiğini savunmuştur. Milliyetçi Hareket Partisi (MHP), Suriye iç savaşının kalıcı bir uzlaşı ile çözülmesi gerektiği ve ardından Suriyelilerin hızlıca ülkelerine dönmeleri gerektiğini savunmuştur. Suriyelilerin oluşturduğu maddi yükün uluslararası organizasyonlarca pay edilmesi gerekliliğini savunan parti kurmaylarının süreç içerisinde sert tonlardaki demeçlerle Türkiye'deki Suriyelilerin karışmış oldukları olaylara işaret ettikleri gözlemlenmiştir. Halkların Demokratik Partisi (HDP) ise seçim sürecinde konu özelindeki en liberal söylemleri geliştirmiş ve mültecilik hukuku konusunda coğrafi çekince şartının kaldırılması gerektiğini savunmuştur. Parti yöneticileri, Geçici Koruma altındaki Suriyelilere vatandaşlık verilebileceğini dillendirmiştir. HDP, seçim sürecinde Türkiye'deki Suriyelilere vatandaşlık önerisinde bulunan ve bu vaat ile Türkiye Büyük Millet Meclisi (TBMM)'de temsil kabiliyeti kazanan tek parti olmuştur. ${ }^{65}$ Takip eden genel seçimlerde göçün siyasallaşması ve benzer görüş ayrılıkları devam etmiştir. Öte yandan Cumhurbaşkanı Erdoğan 2 Temmuz 2016 tarihinde Kilis’te, Türkiye'deki Suriyeliler özelinde yapmış olduğu bir değerlendirmede ilgili gruba vatandaşlık verme çalışmaları olduğunu dile getirmiştir. ${ }^{66}$ Buna karşın kamuoyunda ilgili vaadin önemli bir destek yakalayamadığı gözlemlenmiş ve süreç işlerlik kazanmamıştır. 31 Mart 2019

64 M. Murat Erdoğan, Türkiye'deki Suriyeliler ..., s. 199-200.

65 Ahmet Ceylan ve İsa Uslu, "7 Haziran 2015 Genel Seçimlerinde Partilerin Uluslararası Göç Yaklaşımları Üzerine Karşılaştırmalı İnceleme”, Sosyal Bilimler Araştırma Dergisi, Cilt: VIII, No: (Mart 2019), s. 105-112.

66 T.C Cumhurbaşkanlığı, Haberler, 2 Temmuz 2016, https://www.tccb.gov.tr/haberler/410/45574/suriyeli-kardeslerimizevatandaslik-imkni-verecegiz.html, Erişim Tarihi: 19 Ocak 2019. 
Mahalli İdareler seçimleri öncesi İçişleri Bakanı Süleyman Soylu; 79.820 Suriyelinin Türk vatandaşlığı kazandığını ve bu gruptan reşit olmayanlar düşüldüğünde geriye kalan 53.099 kişinin oy kullanım hakkına haiz olacağını ifade etmiştir. ${ }^{67}$ Seçim sürecinde siyasal partilerin farklılaşan politik yaklaşımları ise güçlenerek devam etmiştir.

Göç kabul sürecinde gözlemlenmesi gereken önemli bir faktör de hedef ülkedeki iş piyasasına giriş koşulları konusunda olmuştur. Türk hukuk sisteminde mülteci ve sı̆̆ınmacıların çalışma izni 4817 sayılı "Yabancıların Çalışma İzinleri Hakkında Kanun" ile ele alınmıştır. Türkiye’ye giriş yapmaya başlayan Suriyelilerin çalışma izinleri sürecin başından itibaren kamuoyunda tartışılan bir husus olmuştur. 2016 yılının Ocak ayında gerçekleştirilen Bakanlar Kurulu toplantısı ile konu yasal olarak ülke politika yapıcıları tarafından gündeme alınmış ve Şubat ayında yürürlüğe girmiştir. Yasal düzenlemeye göre geçici kimlik belgeleri olan Suriyeliler, ilgili belgelerinin hazırlanması sonrası 6 aylık bir sürecin tamamlanması ile ikamet ettikleri illerde çalışma iznine başvuru hakkı elde etmişlerdir. Türkiye, geçici koruma altındaki Suriyelilere ilişkin çalışma izni düzenlemesini hayata geçirirken, konu özelinde bir sınırlama da getirmiştir. Düzenlemeye göre bir işyerinde geçici koruma altındakilerin, genel işçi sayısının \%10’ununu geçemeyeceği hükmü yer almıştır. ${ }^{68}$

Yükseköğretim Kurulu (YÖK) 7 Ocak 2015 tarihinden gerçekleştirilen kurum içi toplantıya atfen alınan kararı kamuoyu ile paylaşmıştır. Kurum; 8 üniversitenin Suriye'den gelen öğrencilerin eğitim ve öğretim hayatlarının aksamaması amacıyla, bu öğrencilerin kabulüne ilişkin Türkçe ve yabancı dilde program açabilmelerine karar kılındığını açıklamıştır. ${ }^{69}$ Türk Kızılayı ve AFAD da süreç içerisinde öncül kurumlar olarak ön plana çıkmıştır. Türk Kızılayı ayni ve nakdi yardım maksatlı akıllı kartların yanı sıra lisan desteği, psikososyal destekler çerçevesinde Suriyelilerin yanında yer almıştır. ${ }^{70}$

AFAD; sağlık desteği, bilgisayar okuryazarlığı ve çeşitli sertifika programları başta olmak üzere çok sayıda maddi ve manevi desteği ile sürecin önemli kurumları arasında yer almıştır. ${ }^{71}$

67 "Bakan Soylu oy kullanacak Suriyelilerin sayısını açıkladı", Hürriyet, 19 Ocak 2019.

68 Doğuş Şimşek, "Göç politikaları ve "insan güvenliği”": Türkiye'deki Suriyeliler örneği”, Toplum ve Bilim, Say1: 140, 2017, s. 20.

69 Yüksek Öğretim Kurumlarında Ön Lisans ve Lisans Düzeyindeki Programlar Arasında Geçiş, Çift Anadal, Yan Dal ile Kurumlar Arası Kredi Transferi Yapılması Esaslarına İlişkin Yönetmelikte Değişiklik Yapılmasına Dair Yönetmelik, 21 Eylül 2013, http://www.resmigazete.gov.tr/eskiler/2013/09/20130921-9.htm, Erişim Tarihi: 19 Ocak 2019.

70 Türk Kızılayı, Göç ve Mülteci Hizmetleri, https:/www.kizilay.org.tr/neler-yapiyoruz/goc-ve-multeci-hizmetleri, Erişim Tarihi: 19 Ocak 2019.

71 AFAD, Suriyeli Sığınmacılara Yapılan Yardımlar, 8 Ağustos 2017, https://www.afad.gov.tr/upload/Node/2373/files/ Suriyeli_Siginmacilara_Yapilan_Yardimlar+7.pdf, Erişim Tarihi: 19 Ocak 2019. 


\section{Sonuç}

Portes ve Böröcz'ün, hedef ülkelerin göçmen kitlelere ilişkin yaklaşımları konusundaki çıkarımları çerçevesinde ele alındığında, Türkiye'ye yönelik Bulgaristan'dan gelen Türk göçünün çeşitli aksaklıklar içermekle birlikte hedef ülke Türkiye'de ana hatlarıyla olumlu bir şekilde karşılandığı söylenebilecektir. Göç sürecinde ülke kamuoyu bileşenlerince ekseri olarak göçmen gruba yönelik olumlu bir tutum ön plana çıkmıştır. Bahsi geçen olumlu tutum; devlet mekanizmasının göçmen gruplara yönelik aktif desteği, ekonomik imkânlar, yasal haklar ve sosyal kolaylıkların göçmen gruplar için hazır hale getirilmesi şeklinde gelişmiştir. Portes ve Rumbaut ise menşe bölgeden daha önce göç etmiş insanların varlığının devletin ve kamuoyunun göçü aktif biçimde kabul etme etmesinde etkili bir faktör olduğunu tartışmışlardır. Bu doğrultuda bir inceleme ile Bulgaristan Türklerinin ilgili bölümde ele alındığ önem arz etmektedir. Söz konusu göç hareketleri, hedef ülke Türkiye'de bir toplumsal hafıza ve refleks geliştirmiştir. Öncül göçmenler, kitlesel sığınma ile gelen göçmenlere hem akrabalık ilişkileri ile sahip çıkmış hem de ülke kamuoyunda oluşan duyarlılığın temel sebepleri arasında yer almışlardır.

Türkiye Cumhuriyeti’nin, kuruluş sürecinde aldığı Balkan göçleri, kurucu kadroların önemli bir bölümünün Osmanlı İmparatorluğu’nun Balkan topraklarında dünyaya gelmiş olmaları ve 1934 tarihli İskân Kanunu ruhu, ilgili göç hareketinin kolaylaştırıcı unsurları arasında yer almıştır. Ulus-devlet kurulum aşamalarının dünyadaki ve Balkan coğrafyasındaki örneklerine paralel olarak, homojen toplum arayışı yeni kurulan Türk devletinin önemli özellikleri arasında yer almış ve göç teşvikinin gerekçelerinden olmuştur.

Nisan 1991'de çoğunluğunu Kürtlerin oluşturduğu, aralarında Arap, Keldani, Nasturi, Türkmen ve Süryani grupların da bulunduğu 467.489 Irak vatandaşının gerçekleştirmiş olduğu kitlesel göç hareketi Türkiye'nin sınır güvenliği çekincesi ile karşılanmıştır. Öncelikli yönelim sınır kapılarının açılmaması olsa da Türkiye'deki Kürt nüfusunun göçmenlerle akrabalığının yaratmış olduğu iç kamuoyu baskısı ve uluslararası çağrılar Türkiye'yi sınır kapılarını açmaya yöneltmiştir. Öte yandan atılan diplomatik adımlar çerçevesinde göçmenlerin önemli bir bölümünün kısa sürede dönmeleri planlanmıştır. Göçmenler, bilhassa sınır hattındaki bölge halkı tarafından sıcak biçimde karşılanırken ülke kamuoyunda da çeşitli destek programları gözlemlenmiştir.

Portes ve Rumbaut, devletin göçü kabul yönelimlerine ilişkin irdelemesinden hareketle Türkiye Cumhuriyeti'nin kurumlarının Suriyelilere yönelik aktif bir kabul politikası yürüttüğü ve bu bağlamda açık kapı politikası izlediği ve ilgili kurum ve 
kuruluşları görevlendirdiği gözlemlenmiştir. Suriye'deki toplumsal krize paralel gelişim gösteren kitlesel sığınma, ilk olarak inanç temelli ve insani vurgularla karşılanmış ancak kısa bir süre içerisinde geçici koruma çerçevesinde kurumsallaşmıştır. Öte yandan göç sürecinin hızlı ve ivmeli gelişimine ek olarak, sürecin uzaması ülkenin emek piyasası ve emlak sektörü başta olmak üzere çeşitli konularda toplumsal tedirginlikler doğurmuştur. Glazer'in tartışmış olduğu üzere hedef ülkedeki yerleşikler, fazla olarak ele alınabilecek sayıdaki göçmenlerin ülkelerindeki kültürel öğelere ve kimlik değerlerine zarar verebileceği çekinceleri yaşamaktadır. Bu durum Türk soylu veya Türk kültüründen göç hareketine aşina olan ve göç belleği bu bağlamda şekillenen Türkiye kamuoyunda da etkili olmuştur. Arap nüfusu başta olmak üzere çok parçalı bir etnik yapıya haiz olan göç hareketinin barındırmış olduğu sayı, sürecin belirsizliği ve bazı altyapısal sorunlar kamuoyu desteğini azaltan öğeler olmuştur. Sürecin Türkiye'de göçü siyasallaştıran ve siyasal partileri farklı yaklaşımlara iten hüviyeti de önemli bir sonuç olmuştur.

Üç göç hareketi de tartışılmış olduğu üzere çeşitli benzerlik ve farklılıklara haiz olmuştur. Süreleri, gelişim süreçleri, ülke içi yayılışları ve karşılanışları çeşitlilik arz etmiştir. Bulgaristan ve Irak göçleri hızlı cereyan etmiştir. Irak göçü ülke içi geniş ölçekli bir yayılım arz etmemiştir. Suriye ve Irak göçlerinde ülke kamuoyunda sınır güvenliği endişesi gelişmiştir. Göçün nasıl karşılandığına ilişkin en belirgin faktörlerden olan vatandaşlık kazanımı konusunda ise sadece Bulgaristan göçmenlerinin toplumsal bir uzlaşıya sahip oldukları gözlemlenmiştir. Irak ve Suriye kaynaklı göçler, farklılaşan biçimlerde Türkiye kamuoyu bileşenlerinden destek görmüştür. Kamuoyunda Irak göçüne ilişkin insani bakış açısı ve özellikle Kürt kökenli yurttaşların olumlu tepkileri öne çıkarken, Suriye göçünde ise insani yardım refleksine ek olarak inanç temelli kimi söylemler gözlemlenmiştir. Buna karşın Türk kültürü ve soyundan olmaya önem atfeden vatandaşlık verme anlayışı konusunda Bulgaristan göçünde ülke kamuoyunda görülen kararlılığın, Suriye ve Irak göçlerinde aynı ölçüde gelişmediği gözlemlenmiştir. Bulgaristan göçünde Türkiye'ye yönelen göçmen grubun Türk soy ve kültüründen olmasına karşın, Irak ve Suriye kaynaklı göçlerde göçmenlerin görece oldukça az bir bölümünün Türkmen gruplarından müteşekkil olması kabul sürecini etkileyen önemli unsurlar arasında yer almıştır. Bu durumun, ulus-devlet anlayışı ve homojen toplum arayışının dünyadaki ve Balkan coğrafyasındaki örneklerine benzer biçimde, Türkiye özelindeki önemli bir tezahürü olduğu söylenebilecektir. Konunun bu çalışmada merkezinde ele alınmış olduğu göç kabul mekanizmalarına ek olarak, farklı çalışmalarda ulus-devlet kuramları çerçevesinde değerlendirilmesi, ilgili süreçlerin karşılaştırmalı analizinde farklı yaklaşımların gelişmesine katkı sağlayabilecektir. 


\section{KAYNAKÇA}

\section{Kitaplar}

Atasoy, Emin:

Bizden Olan Ötekiler. Asimilasyon Klskacında Bulgaristan Türkleri, MKM Yayınc1lık, Bursa, 2011

Babuş, Fikret:

Osmanlı'dan Günümüze Etnik-Sosyal Politikalar Çerçevesinde Türkiye'de Göç ve İskân Siyaseti ve Uygulamaları, Ozan Yayıncılık, İstanbul, 2008.

Bardakçı, Murat: Talat Paşa'nın Evrak-ı Metrukesi, Everest Yayınları, İstanbul 2008.

Bartram, D.; Poros, V. M.; Pierre M.: Göç Meselesinde Temel Kavramlar, çev. Itır Ağabeyoğlu Tuncay, Hece Yayınları, Ankara 2017.

Erder, Sema: Zorla Yerleştirmeden Yerinden Etmeye, İletişim Yayınları, İstanbul, 2018.

Erdoğan, Murat:

Türkiye'deki Suriyeliler, İstanbul Bilgi Üniversitesi Yayınlar1, İstanbul, 2018.

Karpat, Kemal:

Osmanlı'dan Günümüze Etnik Yapılanma ve Göçler, Timaş Yayınları, İstanbul, 2017.

Kaynak, Muhteşem:

Iraklı Slğınmacılar ve Türkiye, Tanmak Yayınları, İstanbul, 1992.

Portes, A., Rumbaut, R.: $\quad$ Immigrant America: A Potrait, University of California Press, California, 1990.

Şimşir, Bilal:

Bulgaristan Türkleri, Bilgi Yayınevi, İstanbul, 2012.

Yıldız, İbrahim:

Türkiye'ye Uluslararası Göçler ve Türkiye'nin Göç Politikası, Kırmızı Çatı Yayınları, Ankara, 2018.

\section{Makaleler}

Ceylan, Ahmet; Uslu, İsa: “7 Haziran 2015 Genel Seçimlerinde Partilerin Uluslararası Göç Yaklaşımları Üzerine Karşılaştırmalı İnceleme", Sosyal Bilimler Araştırma Dergisi, Cilt: VIII, No: 1, 2019, ss. 97-114.

Ciğerci, Nihan:

"Küreselleşme Çağında Göç”, Bursa-Kırcaali Hattı: 1989'da Gelen Bulgaristan Göçmenleri Örneği, Ed: S. G. Ihlamur Öner, N. A. Şirin Öner, İstanbul, İletişim Yayınlar1, 2016, ss. 107-134. 
Çatır, Gül:

Fielden, Alexandra:

Glazer, Nathan:

İçduygu, Ahmet:
“Küreselleşme Çağında Göç”, Zorunlu Göç Tecrübesinin Devlet Politikalarındaki Yansımasi: Bulgaristan'dan Türkiye’ye Kitlesel Göçün Analizi, Ed: S. G. Ihlamur Öner, N. A. Şirin Öner, İstanbul, İletişim Yayınları, 2016, Ss. 217-232.

"Local Integration: an Under-Reported Solution to Protracted Refugee Situation”,UNHCR, Geneva, 2008.

"Arguing Immigration: Are New Immigrants a Wealth of Diversity... or a Crusbing Burden?",The closing door, Ed. Nicolaus Mills, New York: Simon\&Schuster, 1994, pp. 37-47.

"International Migration and Humen Development in Turkey", United Nations Development Programme, Human Development Reports Research Paper, 2009/52, New York, October 2009, pp. 1-45.

İçduygu, A.; Aksel Bayraktar, D.: "Turkish Migration Policies: A Critical Historical Retrospective", Perceptions, Volume: XVIII, No: 3, 2013, pp. 167-190.

İçduygu, Ahmet; Bielh, Kristen: "Kentler ve Göç Türkiye, İtalya, İspanya Örnekleri”, Türkiye’ye Yönelik Göçün Değişen Yörüngesi, Ed: Ahmet İçduygu, İstanbul, İstanbul Bilgi Üniversitesi Yayınları, 2012, s. 9-72.

İçduygu, Ahmet; Toktaş Şule: "How to Smuggling and Trafficking Operate via Irregular Border Crossing in the Middle East? Evidence from Field Work in Turkey", International Migration, Vol: 40, No: 6, 2002, pp. 25-54.

Işık, Mustafa:

"Bir Balkan Trajedisi Olarak Asimilasyon ve Göç Bağlamında Türkiye-Bulgaristan İlişkileri”, Uluslararası Lisansüstü Balkan Çalışmaları Sempozyumu (13-14 Mayıs 2016), İstanbul.

Kirişçi, Kemal, Karaca, Sema: “Türkiye’nin Göç Tarihi”, Hoşgörü ve Çelişkiler: 1989, 1991 ve 2011'de Türkiye’ye Yönelen Kitlesel Mülteci Akınları, Ed. M. Murat Erdoğan, Ayhan Kaya, İstanbul, İstanbul Bilgi Üniversitesi Yayınları, 2015, ss. 295-314.

Konukman, Ercüment: $\quad$ Belgeler Işığııda Büyük Göç ve Anavatan, Ankara, Türk Basın Birliği, 1990. 
Macar, Elçin:

Önder, Selahattin:

Portes, A., Böröcz, J.:

Sarı, Muhammed:

Şimşek, Doğuş:

Vasileva, Darina:

\section{Tezler}

Özlem, Kader:
“Türkiye'nin Göç Tarihi”,Yunanistan'dan Anadolu'ya Göç: Nüfus Mübadelesi, Ed: M. Murat Erdoğan, Ayhan Kaya, İstanbul, İstanbul Bilgi Üniversitesi, Yayınları, 2015, ss. 173-185.

“1913 Türk-Bulgar Mübadelesi”, Yeni Türkiye, No: 31, 2000, ss. 342-346.

"Contemporary Immigration: Theoretical Perspectives on its Determinants and Modes of Incorporation", International Migration Review, Volume: XXIII, No: 3, 1987, pp. 606-630.

“Atatürk Dönemi’nin İskân Politikasında İç İskâna Yönelik Çalışmalar", Hacettepe Üniversitesi Atatürk Ilkeleri ve Inkllâp Tarihi Enstitüsü Cumhuriyet Tarihi Araştırmaları Dergisi, Sayı: 14, 2011, ss. 87-113.

“Göç politikaları ve 'insan güvenliği': Türkiye'deki Suriyeliler Örneği”, Toplum ve Bilim, Say1: 140, 2017, ss. 11-26.

"Bulgarian Turkish Emigration and Return", International Migration Review, Volume: XXVI, No: 2, 1992, pp. 342352.

“Türkiye'nin Balkan Türkleri Politikasının Analizi (19912014)", Yayınlanmamış Doktora Tezi, Trakya Üniversitesi Sosyal Bilimler Enstitüsü Uluslararası İlişkiler Anabilim Dal1, Edirne, 2015.

\section{4. İnternet Kaynakları}

"Bakan Soylu oy kullanacak Suriyelilerin sayısını açıkladı", Hürriyet, 19 Ocak 2019, http://www.hurriyet.com.tr/gundem/bakan-soylu-acikladi-oy-kullanacaksuriyelilerin-sayisi-41087942, Erişim Tarihi: 17.04.2019.

“Geçici Koruma Yönetmeliği”,Türkiye Cumhuriyeti Cumhurbaşkanliğl İdari Işsler Başkanlı̆̆l Hukuk ve Mevzuat Genel Müdürlüğ̈̈, Resmi Gazete, http://www. resmigazete.gov.tr/eskiler/2014/10/20141022.htm, Erişim Tarihi: 11.04.2019.

“Göç ve Mülteci Hizmetleri”, Türk Kızllayı, https://www.kizilay.org.tr/neler-yapiyoruz/ goc-ve-multeci-hizmetleri, Erişim Tarihi: 15. 04. 2019. 
“Göç ve Uyum Raporu”, Türkiye Büyük Millet Meclisi Insan Haklarını Inceleme Komisyonu Mülteci Haklarl Alt Komisyonu, https://www.tbmm.gov.tr/komisyon/ insanhaklari/docs/2018/goc_ve_uyum_raporu.pdf, Erişim Tarihi: 13.04.2019.

“İçişleri Bakanı Muammer Güler: Saldırganlar tespit edildi”, Hürriyet, 12 Mayıs 2013, http://www.hurriyet.com.tr/gundem/icisleri-bakani-muammer-guler-saldirganlartespit-edildi-23260495, Erişim Tarihi: 17.04.2019.

“Kitlesel Akınlar”,Türkiye Cumhuriyeti İçişleri Bakanlığı Göç İdaresi Genel Müdürlüğü, http://www.goc.gov.tr/icerik3/kitlesel-akinlar_558_558_559, Erişim Tarihi: 12.04.2019.

“Seçimlerde oy kullanacaklar mı?”, Milliyet, 19 Ağustos 2013, http://www.milliyet.com. tr/secimlerde-oy-kullanacaklar-mi--siyaset-1751799/, Erişim Tarihi: 17.04.2019.

“Suriye'de içsavaş 3'üncü y1lında”, Hürriyet, 15 Mart 2013, http://www.hurriyet.com.tr/ gundem/suriyede-icsavas-3uncu-yilinda-22824015, Erişim Tarihi: 17.04.2019.

"Suriyeli Sığınmacılara Yapılan Yardımlar”, Afet ve Acil Durum Yönetimi Başkanlı̆̆l, https://www.afad.gov.tr/upload/Node/2373/files/Suriyeli_Siginmacilara_Yapilan_ Yardimlar+7.pdf, Erişim Tarihi: 10.04.2019.

“Suriyeli sayısı 100 bini geçerse...", Sabah, 20 Ağustos 2012, https:/www.sabah.com. tr/dunya/2012/08/20/suriyeli-sayisi-100-bini-gecerse, Erişim Tarihi: 17.04.2019.

"Suriyeli Kardeşlerimize Vatandaşlık İmkânı Vereceğiz", Türkiye Cumhuriyeti Cumhurbaşkanlığl, Haberler, https://www.tccb.gov.tr/haberler/410/45574/suriyelikardeslerimize-vatandaslik-imkni-verecegiz.html, Erişim Tarihi: 14.04.2019.

“2510 Sayılı İskân Kanunu”, Türkiye Cumhuriyeti Cumhurbaşkanlı̆̆ı İdari İşler Başkanlı̆̆l Hukuk ve Mevzuat Genel Müdürlüğ̈̈, Resmi Gazete, http://www. resmigazete.gov.tr/arsiv/2733.pdf, Erişim Tarihi: 11.04.2019.

“6458 Sayıl1 Yabanc1lar ve Uluslararası Koruma Kanunu (YUKK)”, Türkiye Cumhuriyeti Cumhurbaşkanlığı İdari Işsler Başkanlığl Hukuk ve Mevzuat Genel Müdürlüğ̈̈, Resmi Gazete, http://www.mevzuat.gov.tr/MevzuatMetin/1.5.6458.pdf, Erişim Tarihi: 11.04.2019. 
